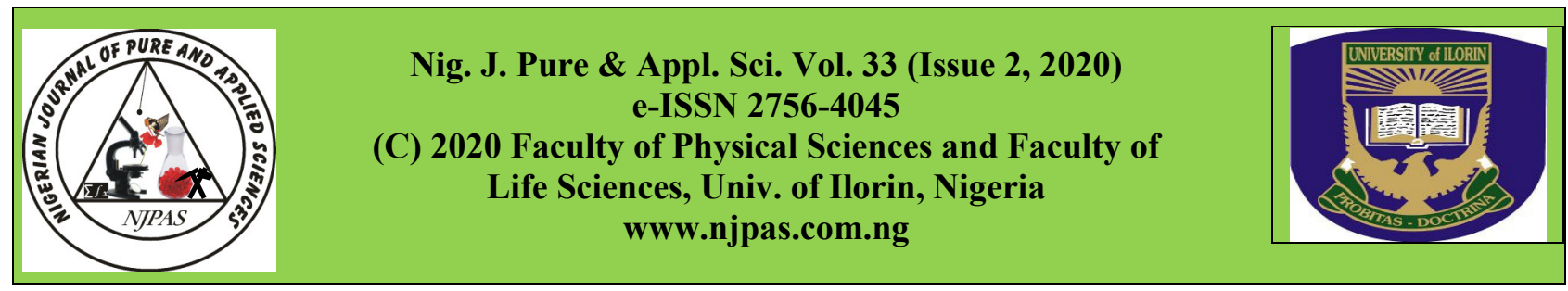

\title{
http://dx.doi.org/10.48198/NJPAS/20.B07 \\ Prevalence of Herpes Simplex Virus type 2 IgM among Women of Reproductive Age in Zaria, and Demonstration of its Cytopathogenicity in Whole Egg
}

Ameh, E.R., Aminu, M., and Ella, E. E*.

Department of Microbiology, Ahmadu Bello University, Zaria

\section{ABSTRACT}

Egg culture has long been considered the diagnostic gold standard for Herpes Simplex Virus type 2 (HSV2) and would serve as complementary to Immunoglobulin $M$ determination to establish acute infection in a given population. The study determined the prevalence of HSV-2 IgM and the cytopathology of the virus isolated from women of reproductive age in Zaria. The study recruited 450 consenting women attending selected hospitals from which blood and cervical swab samples were obtained. Sera were analysed for HSV-2 IgM while suspension from swabs were inoculated into 12 days old embryonated chicken eggs. A total of 330 (73.3\%) women screened tested positive for HSV-2 IgM and 79 (23.94) out of $330 \mathrm{IgM}$ positive samples produced cytopathic effect. The highest prevalence of $88.7 \%$ (133/150) was recorded among women recruited from St. Lukes Anglican hospital, while those attending Gambo Sawaba General Hospital-Kofan Gaya, had the lowest prevalence of 50\%. Furthermore, women in age group of 16-20 years, were most infected with a prevalence of $83.5 \%$ while those aged 45years and above had the lowest prevalence of $50 \%$. Women who had more than one sexual partner, those that did not use protection during sex and women that were pregnant had higher prevalence of $88.5 \%, 74.9 \%$ and $77.6 \%$ respectively and were more at risk, as compared with those with single partner $(69.2 \%)$, who used protection (61.5\%) and that were not pregnant $(71.3 \%)$. About $22.4 \%$ (101) of the women reported to have heard about HSV-2 while 349 (77.6\%) were not aware of the virus prior to this study. The symptoms found to be significantly associated with the virus were blisters/ulcers on genital area $(p=0.000 ; O R=3.000)$ and dysuria $(p=0.006 ; O R=0.504)$. Fever $(O R=1.659)$, vaginal discharge $(\mathrm{OR}=1.867)$ and itching/burning sensation on genital area $(\mathrm{OR}=1.431)$ were other symptoms associated with the virus. The study demonstrated a high prevalence of HSV-2 among the women, indicating that, genital herpes is highly endemic in the study area. In addition, a substantial number of the women lacked knowledge of genital herpes and were actively harbouring the virus.

Keywords: Prevalence, Cytopathic effect, HSV-2 IgM, Zaria

\section{Introduction}

Egg culture has long been considered the gold standard for HSV-2 with specificity of $100 \%$. However, levels of virus shedding, specimen

quality and transport conditions may influence its sensitivity (Paz-Bailey et al., 2007). HVS-2 establishes a lytic infection in the epithelial cells,

Corresponding Author: Ella, E. E.

Department of Microbiology, Ahmadu Bello University, Zaria; Phone: $+2348023634081 ; 07010454860$ :

Email: elijahella33@yahoo.com; eeella@abu.edu.ng 
eliciting tissue destruction which is characterized by complex cell death pattern and latency within the neurons (Nguyen and Blaho, 2007; Pellett and Roizman, 2007). Systemic and local stress factors as occasioned by hormonal changes, pregnancy,

Page | 3800 fever, exposure to direct sunlight and several underlying diseases, can interfere with the viral latency thereby inducing viral reactivation and recrudescent infections. The cytopathogenic mechanism of diseases caused by HSV-2 involves indirect immune processes and direct virusmediated events (Kaye and Choudhary, 2006; Fatahzadeh and Schwartz, 2007). Viral infection induces balloon formation in cells with condensed chromatin with the nuclei and nuclear degeneration within parabasal intermediate cell of the epithelium. This result in the formation of multinucleated giant cells caused by lose of plasma membranes. These cells form vesicles between the epidermis and dermal layer of the skin containing clear fluid with large quantity of viral particles and cellular debris. The cellular debris results from inflammatory response in the corium of the skin in the course of primary herpes. In the process of recovery and healing the vesicular fluid becomes pustular due to the accumulation of inflammatory cells and sometimes forms scabs. The vesicles become replaced by shallow ulcers in cases involving the mucous membranes, however, scarring is uncommon (Richman et al., 2017).

HSV-2 is prevalent in several developing countries of Asia, North America and Northern Europe (Weiss, 2004). The reported prevalence HSV-2 among women in the African continent indicates $22 \%$ in Tanzania, $68 \%$ in Kenya and $90 \%$ among commercial sex workers in Zaire (Agabi et al., 2010). Furthermore, age- and sexspecific prevalence of $59 \%$ was reported for HSV2 among commercial sex workers within ages 25 and 26 years in Lagos, Nigeria (Dada et al., 1998). Several risk factors have been associated with HSV-2 and prominent among them are older age, multiple sexual partners, working in brothels and hotels, persistent HIV-1 infection, recent Genital Ulcer Disease (GUD) or Sexually Transmitted Infections (STI) symptoms, lower educational level and female gender (WatsonJones et al., 2007; Chohan et al., 2009; Arama et al., 2010; Okuku et al., 2011; Mugo et al., 2011; Ivete et al., 2014). The study aimed at determining the prevalence of HSV-2 IgM, cytopathic pattern of the virus in egg culture and the possible factors that predisposes the women to HSV-2 in the study area.

\section{Materials and Methods Study Area}

Zaria metropolis where the study was conducted is located on latitude $11^{\circ} 04^{\prime} \mathrm{N}$ and longitude $7^{\circ} 42^{\prime} \mathrm{E}$. It is home to the old Zaria Emirate in Kaduna State in North and comprise of Zaria and Sabon Gari local Government Areas. The city is largely heterogeneous city with a population of about $1,490,000$ of people drawn from different ethnic mix in which Muslim the Hausas and Fulanis predominate. The city houses several Federal Institutions thus attracting people from different states as well as others who come from different parts of the world. It is the gateway to several states in the North and thus provides the unique and multicultural population ideal for the conduct of the study (Oladimeji and Ojibo, 2012).

\section{Study Population}

The study was conducted among women of reproductive age within the ages of 15-49 years old, attending selected secondary hospitals spread across two local Government Areas (LGAs) in Zaria metropolis.

\section{Study Design}

A cross sectional, hospital-based study where equal number of samples were collected from consenting women attending selected hospitals, using a simple randomized sampling technique 
The study population was drawn from three hospitals located in Zaria metropolis. Two of the hospitals, St. Luke's Anglican Hospital Wusasa and Gambo Sawaba Hospital, Zaria City are located in Zaria LGA while Major Ibrahim Bello Page | 3801 Memorial Hospital is located in Sabon-Gari LGA. These hospitals serve a large population of women seeking various gynaecological services. Women that were not within the defined age bracket as well as those that declined consent were excluded from the study. A structured questionnaire was administered to obtain information on sociodemographic variables and possible factors that predisposes the women to HSV-2 in the study area. Ethical approval was granted by the Kaduna State Ministry board of Ethics (Ref$\mathrm{MOH} / \mathrm{ADM} / 744 / \mathrm{Vol} .1$ )

\section{Determination of Sample Size}

The sample size was arrived at using the equation by Naing et al. (2006), and a prevalence of $44.3 \%$ (Kalu, 2013) at 95\% confidence interval.

$\mathrm{n}=\mathrm{z}^{2} \mathrm{pq} / \mathrm{d}^{2}$

$\mathrm{n}=(1.96)^{2} \times 0.443 \times 0.557 /(0.05)^{2}=379.17$

The calculated minimum size was 379.17; however, 450 blood samples were collected for the assay.

\section{Collection of Samples}

Venous blood samples were collected from 450 women aseptically into $5 \mathrm{ml}$ plain vacutainer tubes through venipuncture with the assistance of a qualified and certified medical personnel. The blood was allowed to clot and the serum was separated into plain sample bottles using a micropipette. The sera obtained were refrigerated $\left(-20^{\circ} \mathrm{C}\right)$ till required for use.

Vaginal swabs were also collected aseptically from the women with the assistance of the nurse in the ward using a sterile cotton swab stick. Thereafter swab sticks were transferred into sterile transport medium ( $2 \mathrm{ml}$ of Balanced Salt Solution) in Bijou bottles and transported in icepacks to the Laboratory for further analysis.

\section{Determination of $\mathrm{HSV}-2$ IgM in the Patient's Sera Using ELISA}

Sera were analyzed using the Enzyme Linked Immuno-Sorbent Assay-ELISA (Diagnostic Automation / Cortez Diagnostics USA) according to the manufacturer's instruction. An appropriate dilution (1:40) of the patient's samples and controls (negative, positive control, and calibrator) were prepared and $100 \mu 1$ was dispensed into the appropriate wells. Well A1 was set as blank into which $100 \mu 1$ of the sample diluent was added. The plates were tapped to effect proper mixing and removal of bubbles after which they were incubated at room temperature $\left(28^{\circ} \mathrm{C}\right)$ for $30 \mathrm{~min}$. The wells were then aspirated and repeatedly washed thrice with washing buffer followed by the addition of $100 \mu 1$ of enzyme conjugate and incubation for about 30 minutes at room temperature. At the end of incubation time, the enzyme conjugate was aspirated once again and washing was repeated as done before. Thereafter, $100 \mu 1$ of Tetra Methyl Benzidine (TMB) chromogenic substrate was dispensed in to the wells and the plates were further incubation as before. At the end of incubation, the reaction was stopped by the addition of $100 \mu \mathrm{l}$ of $(2 \mathrm{~N}) \mathrm{HCl}$ and the plates were read at $450 \mathrm{~nm}$ with a microwell reader and interpreted as either negative or positive. To obtain the cut off optical density (O.D) value, the O.D of calibrator was multiplied by the Factor (f) printed on label of calibrator. The IgM Index of each sample was calculated by dividing the O.D values of each sample by the obtained O.D value of cut off calibrator

\section{Cultivation of $\mathrm{HSV}-2$ in Whole egg and demonstration of Cytopathic Effect}

Egg preparation and candling: Eggs for viral cultivation were obtained from the National Animal Production Research Institute, Shika. The eggs were transported to the Virology Laboratory 
of the Department of Microbiology Ahmadu Bello University Zaria and were incubated at $37^{\circ} \mathrm{C}$ for 12 days, preparatory to egg inoculation. Prior to inoculation, the eggs were candled in a process where the eggs were placed at the orifice of a Page | 3802 candling box and the airspace as well as the veins marked to determine the route of inoculation and to prevent piercing the veins, which may lead to bleeding and death of the embryo (Rodgers, 1981).

Egg Inoculation: The vaginal swabs were brought to room temperature, vortexed in $2 \mathrm{mls}$ of balanced salt solution to suspend the viral particles present in the swab before inoculation into the chorioallantoic membrane of the eggs. Briefly: the egg was placed on its side in a plate; the surface of the egg was disinfected with $70 \%$ alcohol and iodine tincture before inoculation. Using an egg punch / egg borer, the airspace was punctured as well as the route for the chorioallantoic membrane. A slight pressure was placed on the airspace, to allow for the collapse of the chorioallantoic membrane, after which $100 \mu \mathrm{l}$ of the viral suspension was placed on the chorioallantoic membrane of the egg using a sterile needle and syringe and the punch was sealed, using candle wax. The inoculated eggs were incubated in a humid incubator at $37^{\circ} \mathrm{C}$ for 5days (Rodgers, 1981).

Observation of Inoculated Eggs for Cytopathic / Plaque Formation: The eggs were observed for formation of plaques/growth after 5 days of incubation and plaques were indicated as viral particle and were correlated with the results of the IgM antibodies present in the study population.

\section{Results}

The result showed that 330 women representing a prevalence of $73.3 \%$ were IgM positive and 79 out of $330(23.94 \%)$ samples produce cytopathic effect as evident in plaque formation (Fig. 1). The prevalence observed among the women from St. Lukes Anglican Hospital Wusasa, was 88.7\% $(133 / 150)$ which was the highest, while those that attended Gambo Sawaba General Hospital-Kofan Gaya, had the least prevalence of $50 \%$ and this variation was statistically significant $\left(\chi^{2}=64.705\right.$, $\mathrm{p}=0.000$ ) (Table 1). Furthermore, a statistically significant association $(p=0.011)$ was observed in relation with the ages of the women with women within age group 16-20 years, being most infected with a prevalence of $83.5 \%$ while those aged $45 y e a r s$ and above had the least prevalence of $50 \%$ (Fig.2).

Women who had more than one sexual partners, who did not use protection during sex and were pregnant had higher prevalence of $88.5 \%, 74.9 \%$ and $77.6 \%$ respectively and were more at risk, as compared with those with single partner $(69.2 \%)$, who used protection (61.5\%) and were not pregnant $(71.3 \%)$. Number of sexual partners $(p=0.000)$ and use of protection $(p=0.041)$ were significantly associated with the virus while pregnancy status was not $(\mathrm{p}=0.159)$ (Table 2.)

Most of the women (349) had no knowledge of HSV -2 with $267(76.5 \%)$ testing positive while 101 indicated that they knew about it among which, 63 (62.4\%) were positive. Similarly, 383 women were not aware of their HSV status, although 291 (76.0) were positive while of the 67 that had knowledge of their status, only 39 (58.2\%) were positive. The association was statistically significant $(\mathrm{p}=0.005)$ (Table 2$)$.

Women with symptoms of fever vaginal discharges, itching sensation, blisters dysuria and pains were $273,129,155,114,86$ and 261 with percentage prevalence of $77.3,81.4,76.8,86.8$, 61.6 and 72.4 respectively. The symptoms that were statistically associated with $\mathrm{HSV}-2$ were Blisters/ ulcers on genital area $(p=0.000 ; O R=$ 3.000 ) and dysuria (pain during urination) $(\mathrm{p}=0.006)$. Symptoms such as fever, vaginal discharge and itching/burning sensation on genital area were relatively associated with HSV-2 infection with Odds ratio of 1.659, 1.867 and 1.431 respectively (Table 3 ). 
Table 1: Prevalence of HSV-2 among Women of Reproductive Age in Relation to Selected Hospitals

\begin{tabular}{ccccc}
\hline Hospital & No Examined & No Positive (\%) & $\chi^{2}$ & P-Value \\
\hline SLAH & 150 & $133(88.7)$ & 64.705 & $0.000^{*}$
\end{tabular}

Page | 3803

$\begin{array}{lll}\text { MIBMH } & 150 & 122(81.3) \\ \text { GSGH } & 150 & 75(50.0) \\ \text { Total } & 450 & 330(73.3)\end{array}$

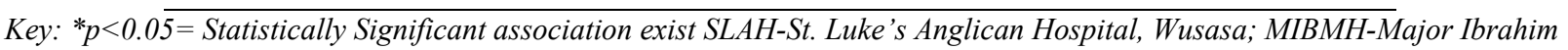
Bello Memorial Hospital, Sabon-Gari; GSGH-Gambo Sawaba General Hospital, Zaria city all in Zaria Metropolis

Table 2: Prevalence of HSV-2 among Women of Reproductive Age in Relation to Some Risk Factors

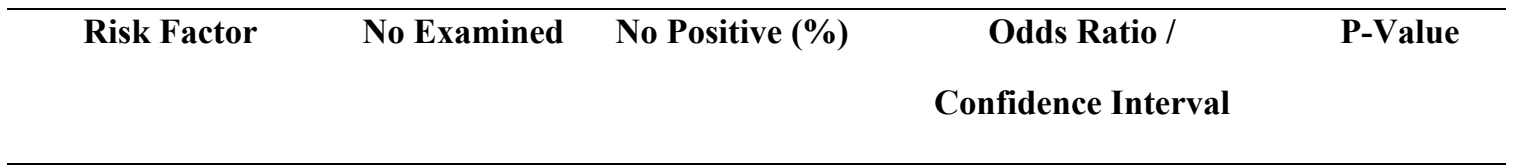

No of Sexual Partners

$\begin{array}{lcccc}\text { Single } & 354 & 245(69.2) & 0.291(0.15-0.57) & 0.000^{*} \\ \text { Multiple } & 96 & 85(88.5) & & \end{array}$

Use of Protective device during sex

$\begin{array}{lrrrr}\text { Yes } & 52 & 32(61.5) & 0.537(0.29-0.98) & 0.041^{*} \\ \text { No } & 398 & 298(74.9) & & \end{array}$

Pregnancy Status

$\begin{array}{ccccc}\text { Pregnant } & 147 & 114(77.6) & 1.391(0.88-2.21) & 0.159 \\ \text { Not pregnant } & 303 & 216(71.3) & & \end{array}$

Awareness of Genital Herpes/HSV-2

$\begin{array}{lllll}\text { Yes } & 101 & 63(62.4) & 0.509(0.32-0.82) & 0.005 \\ \text { No } & 349 & 267(76.5) & & \end{array}$

Awareness of HSV-2 Status

$\begin{array}{ccccc}\text { Yes } & 67 & 39(58.2) & 0.440(0.26-0.76) & 0.002 \\ \text { No } & 383 & 291(76.0) & & \\ \text { Total } & 450 & 330(73.3) & \end{array}$


Table 3: Prevalence of HSV-2 among Women of Reproductive Age in Relation to Some Disease Symptoms

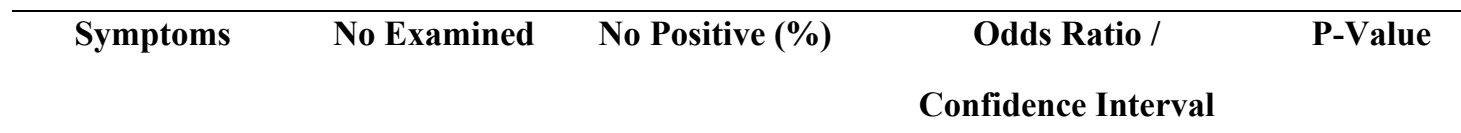

Fever

$\begin{array}{lll}\text { Yes } & 273 & 211(77.3) \\ \text { No } & 177 & 119(67.2)\end{array}$

Vaginal Discharge

$\begin{array}{lll}\text { Yes } & 129 & 105(81.4) \\ \text { No } & 321 & 225(70.1)\end{array}$

Itching/Burning sensation on Genital Area

$\begin{array}{lllll}\text { Yes } & 155 & 119(76.8) & 1.431(1.51-4.04) & 0.232 \\ \text { No } & 295 & 211(71.5) & & \end{array}$

Blister, Ulcers on Genital Area

$\begin{array}{lllll}\text { Yes } & 114 & 99(86.8) & 3.000(1.66-5.41) & 0.000^{*} \\ \text { No } & 336 & 285(71.6) & & \end{array}$

Dysuria (Pain During Urination)

$\begin{array}{lrrrr}\text { Yes } & 86 & 53(61.6) & 0.504(0.31-0.83) & 0.006^{*} \\ \text { No } & 364 & 277(76.1) & & \end{array}$

Feeling of Pain on thigh, Back, Knees and Buttocks

$\begin{array}{ccccc}\text { Yes } & 261 & 189(72.4) & 0.894(0.58-1.37) & 0.604 \\ \text { No } & 189 & 141(74.6) & & \\ \text { Total } & 450 & 330(73.3) & & \end{array}$

\section{Discussion}

The overall prevalence of HSV-2 IgM amongst the women in Zaria was found to be $73.3 \%$. This percentage is higher than the $59 \%$ reported in a study involving commercial sex workers conducted in Lagos-Nigeria (Dada et al., 1998) and $44.3 \%$ amongst antenatal clinic attendees in Benin City, Nigeria (Kalu, 2013). Higher prevalence of HSV-2 have been reported in four sub-Saharan African cities; $90 \%$ in Cotonou,
Benin Republic, 84.1\% in Yaounde, Cameroun, 93.9\% in Kismu, Kenya and $87.7 \%$ in Ndola, Zambia (Weiss, 2004). Furthermore, a study among women with STIs in Jos, Nigeria reported a prevalence of $87 \%$ (Agabi et al., 2010). The high HSV-2 prevalence reported in this study among pregnant women contrast reports from sub-Saharan Africa (40\%), Latin America (30\%), North America $(17-22 \%)$ and Europe $(2-$ 24\%) (Anzivino et al., 2009). Studies from Sweden, Switzerland and China have also shown 
HSV-2 prevalence especially among antenatal women to be $20.7 \%$ and $10.8 \%$ (Berntsson et al., 2000; Chen et al., 2005)

The high prevalence obtained in this study could Page $\mid 3805$ be due to sexual activities engaged in by the women and other stressors such as pregnancy, hormonal disturbances that reactivates the virus/infection. Infection was found to be significantly associated with the selected hospital location $(\mathrm{p}=0.006)$.

Sex remains one of the means of transmission of HSV-2; although genital herpes is not classified as a sexually transmitted disease but regarded as a sexually transmitted viral infection. These women were within the sexually active age and were pregnant. Pregnancy is characterized with hormonal disturbances and other stressors which could predispose these women to the virus or reinfection (Kaye and Choudhary, 2006; Fatahzadeh and Schwartz, 2007). The virus was highly endemic in the communities where the hospitals were situated and could have resulted from to lack of knowledge and awareness about the mode of transmission of the virus. Many cell culture techniques have been employed in the cultivation of HSV-2. The use of the traditional whole egg proved useful in this work which is cheap and easy to use. The study demonstrated cytopathogenic effect (CPE)/plaques characteristic of the virus in $23.9 \%$ of the IgM positive samples. This is within the range of $19-$ $27 \%$ for crusted lesions but lower than that for vesicles (52-93\%) and ulcers (41-72\%) (Scoular et al., 2002).

Immunity decreases with increase in age leading to increase in susceptibility to infectious agents. Increase in sexual activities and negative life style increases the chances of contracting STDs including HSV-2. These observations could also be responsible for the statistically significant association $(p=0.011)$ observed between HSV-2 and women within age group 16-20 years. This observation is in agreement with the report of previous studies in Jos and Zaria (Agabi et al., 2010; Ameh et al., 2016).

Number of sexual partners was found to be significantly $(p=0.001)$ associated with HSV- 2 infection in this study, as also reported by several findings which reported higher prevalence of HSV-2 infection among patients with multiple sexual partners (Auvert and Buve, 2001; Weiss, 2004; Mehta et al., 2008). The use of protection was also found to be statistically associated with the infection, $(p=0.041)$ which is in agreement with the report of Biswas et al. (2011). In contrast, Agabi et al. (2010) and Dada et al. (1998) reported that the use of protection during sexual activity, had no statistical significance to HSV - 2 infection. Pregnancy was also found not to be statistically associated with the infection ( $p$ $=0.159$ ). Pregnancy has been reported by several workers to be a stressor on women which could lead to or cause reactivation of the virus from its latent state and primary exposure to the virus (Biswas et al., 2011; Bochner et al., 2013).

The symptoms found to be statistically associated with HSV-2 were blisters/ ulcers on genital area and dysuria (pain during urination) $(p=0.006)$. This result agrees with the reports of Biswas et al. (2011) and Bochner et al. (2013). Women with fever, vaginal discharge and itching/burning sensation on genital area were more likely to be infected with HSV-2 with Odds ratio of $1.659,1.867$ and 1.431 respectively; however, the associations were not statistically significant.

\section{Conclusion}

The study established that a significant number of women were positive for HSV-IgM and were actively harbouring the virus as demonstrated by the cytopathic result. This is an indication that HSV-2 is highly endemic in the communities where the hospitals were situated and could have resulted from lack of knowledge and awareness about the virus and its mode of transmission. It 
was also found that women in age group 16-20 years were most infected.

Furthermore, pregnant women who had multiple sexual partners and who did not use protection Page | 3806 during sexual intercourse had higher prevalence and were more at risk of HSV-2.

\section{References}

Agabi, Y.A., Banwat, E.B., Mawak, J.D., Lar P.M., Dashe, N. and Dashen, M.M. (2010). Prevalence of Herpes Simplex Virus Type-2 among Patients Attending the Sexually Transmitted Infections Clinics in Jos, Nigeria. Journal of Infection in Developing Countries, 4:572-575.

Ameh, R.E., Aminu, M, and Ella, E.E. (2016) Seroprevalence of HSV-2 among Women of Reproductive Age in Zaria, Kaduna State. Biology and Medicine (Aligarh) 8 (7): $2-6$.

Anzivino, E., Fioriti, D. and Mischitelli, M. (2009). Herpes Simplex Virus Infection in Pregnancy and in Neonate: Status of Art of Epidemiology, Diagnosis, Therapy and Prevention, Biomedical Central Virology Journal, 6:40 - 51.

Arama, V., Cercel, A.S., Vladareanu, R., Mihai, C. and Mihailescu, R. (2010) Type-specific Herpes Simplex Virus-1 and Herpes Simplex Virus-2 Prevalence in Romania: Comparison of Prevalence and Risk Factors in Women and Men. International Journal of Infectious Diseases, 14 (Suppl 3):25-31.

Auvert, B. and Buve, A.F. (2001). Ecological and Individual Level Analysis of Risk Factors for HIV Infection in Four Urban Populations in Sub-Saharan Africa with different levels of HIV infection. Acquired Immunodeficiency Diseases Syndrome 154: 515-530.
Berntsson, M., Tunback, P., Ellstrom, A., Krantz, I. and Lowhagen, G.B. (2000) Decreasing Prevalence of Herpes Simplex Virus 2 antibodies in Selected Groups of Women in Sweden. Acta Dermatology and Venereology 89: 623-626.

Biswas, D., Borkakoty, B., Mahanta, J., Walia, K., Saikia, L., Akoijam, B.S., Jampa, L., Kharkongar, A. and Zomawia, E. (2011). Seroprevalence and Risk factors of Herpes Simplex Virus Type 2 infection among Pregnant Women in Northeast India. Biomedical central Infectious Diseases, 11: $325-334$.

Bochner, A.F., Madhivanan, P., Niranjankumar, B., Ravi, K., Arun, A., Krupp, K. and Klausner, J.D. (2013) The Epidemiology of Herpes Simplex Virus Type-2 Infection among Pregnant Women in Rural Mysore Taluk, India Journal of Sexually Transmitted Diseases 6:1-6.

Chen, K.T., Segu, M., Lumey, L.H., Kuhn, L., Carter, R.1., Bultery, M. and Abram, E.J. (2005). New York Perinatal AIDS collaborative transmission study (PACTS) group: Genital Herpes Infection and Perinatal Transmission of Human Immunodeficiency Virus. Obstetrics and Gynecology 106: 1341- 1348.

Chohan, V., Baeten, J.M., Benki, S., Graham, S.M. and Lavreys, L. (2009). A Prospective Study of Risk Factors for Herpes Simplex Virus Type 2 Acquisition among High-Risk HIV-1 Seronegative Women in Kenya. Journal of Sexually Transmitted Diseases, 85: $489-492$

Dada, A.J., Ajayi, A.O. and Diamondstone, L. (1998). A Sero-Survey of Haemophilus ducreyi, Syphilis, and Herpes Simplex Virus Type-2 and their Association with HIV among Female Sex Workers in Lagos, 
Nigeria. Journal of Sexually Transmitted Diseases, 25: 237- 242.

Fatahzadeh, M. and Schwartz, R. (2007). Human Herpes Simplex Virus Infections: Page | $3807 \quad$ Epidemiology, Pathogenesis, Symptomatology, Diagnosis, and Management. Journal of the American Academy of Dermatology, 57: 737-763.

Ivete, M., Karine, D., Paul, J., Archie, C.A., Arlinda, Z., Fidelina, C., Pai, L.C., Josefo, J. and Janneke, H.V.W. (2014). Prevalence, Incidence and Determinants of Herpes Simplex Virus Type 2 Infection among HIV-Seronegative Women at High-Risk of HIV Infection. Clinical and Vaccine Immunology, 18: 655-660.

Kalu, E.I. (2013). Prevalence of Herpes Simplex Virus Infections among Pregnant Women Attending Antenatal Clinic in Benin, Nigeria. International Journal of Tropical Diseases and Health, 4:1-12.

Kaye, S. and Choudhary, A. (2006) Herpes Simplex Keratitis. Progress in Retinal and Eye Research, 25, 355-380.

Mehta, S.D., Moses, S., Agot, K., Agingu, W., Parker, C., Ndinya-Achola, J.O. and Bailey, R.C. (2008). Herpes Simplex Virus Type 2 Infection among Young Uncircumcised Men in Kisumu, Kenya. Journal of Sexually Transmitted Diseases. 84: 42-48.

Mugo, N., Dadabhai, S.S., Bunnell, R., Williamson, J. and Bennett, E. (2011). Prevalence of Herpes Simplex Virus Type 2 Infection, Human Immunodeficiency Virus/herpes Simplex Virus Type 2 Coinfection, and Associated Risk Factors in a National, Population-Based Survey in Kenya. Journal of Sexually Transmitted Diseases, 38: 1059-66.
Naing, L., Winn, T. and Rushi, B.N. (2006). Practical Issues in Calculating the Sample Size for Prevalence Studies. Archives of Orofacial Sciences, 1:9-14.

Nguyen, M.L. and Blaho, J.A. (2007). Apoptosis during Herpes Simplex Virus Infection. Advance in Virus Research, 69: 67-97.

Okuku, H.S., Sanders, E.J., Nyiro, J., Ngetsa, C. and Ohuma, E. (2011). Factors Associated with Herpes Simplex Virus type 2 Incidence in a Cohort of Human Immunodeficiency Virus Type 1-Seronegative Kenyan Men and Women Reporting High-risk Sexual Behavior. Journal of Sexually Transmitted Diseases, 38: 837-844.

Oladimeji, J.S. and Ojibo, S.D. (2012). Governance perceptions of informal enterprise operators in Zaria, Nigeria. American International Journal of Contemporary Research, 2(10): 150-159

Paz-Bailey, G., Ramaswamy, M., Hawkes, S.J. and Geretti, A.M. (2007). Herpes Simplex Virus Type 2; Epidemiology and Management Options in Developing Countries. Journal of Sexually Transmitted Diseases, 83: 16-22.

Pellett, P.E. and Roizman, B. (2007). The Family Herpesviridae: a brief introduction. In D.M. Knipe, P.M. Howley, D.E. Griffin, R.A. Lamb, M.A. Martin, B. Roizman and S.E. Straus (Eds.), Fields Virology (5th edn.). Philadelphia, PA: Lippincott Williams and Wilkins pp. 2479-2499

Richman, D. D., Whitley, R.J. and Hayden, F. G. (2017). Clinical virology $\left(4^{\text {th }}\right.$ edn $)$ Washington, DC: ASM Press, Pp 415-466

Rodgers, F.G. (1981). Growth of Herpes Simplex Virus Types 1 and 2 in Tissues of Fertile Hens' Eggs In-Ovo and In-Vitro. British 
Journal of Experimental Pathology 62: 317 $-322$

Scoular, A., Norrie, J., Gillespie, G., Mir, N. and Carman, W.F. (2002). Longitudinal study of genital infection by herpes simplex virus type 1 in Western Scotland over 15 years. British Medical Journal 324:1366-1367

Watson-Jones, D., Weiss, H.A., Rusizoka, M., Baisley, K. and Mugeye, K. (2007). Risk Factors for Herpes Simplex Virus Type 2 and HIV among Women at High Risk in
Northwestern Tanzania. Journal of Acquired Immune Deficiency Syndromes, 46: 631-42.

Weiss, H. (2004). Epidemiology of Herpes Simplex Virus Type 2 Infection in the Developing World. Herpes 11(Suppl 1): 24A-35A 